\title{
REFORESTATION PLANNING BASED ON PLANT HARDINESS ZONES IN VITILEVU ISLAND, FIJI
}

\author{
D. L. Cornelio \\ Faculty of Agriculture, Forestry \& Fisheries, SINU, R113 Honiara, Solomon Islands - David.Cornelio@sinu.edu.sb
}

KEY WORDS: Land use planning, reforestation, GIS modelling, Fiji Islands

\begin{abstract}
:
Significant land use changes in Fiji Islands caused soil degradation, pollution and biodiversity losses. The planting of trees is an option of sustainable land use with long term ecological and economic advantages. Spatial models based on ecological requirements of tree species facilitates decision making, planning and risks management before planting. A land suitability analysis with Geographic Information System (GIS) was carried out to identify areas in Vitilevu island for the planting of eleven native and exotic tree species. Altitudes, rainfall and forest cover maps were used as discrimination factors in boolean operations. The species with higher ecological potential for plantation were Syzygium decussatum (22\% of the total area), Tectona grandis (19\% of the total area), and Metroxylon vitiense (18\% of the total area). The model is robust but can be enhanced by adding thematic layers of other environmental factors.
\end{abstract}

\section{INTRODUCTION}

Over the last 20 years irrational logging of natural tropical forests worldwide shifted into sustainable management plans and plantations (Evans 1992) of varied composition, scale, complexity, and purpose. They are reported to halt deforestation, increase timber production, and improve soil and water quality and wildlife habitat (Nambiar 1999); in Fiji, the clearing of large areas for the planting of sugar-cane, coconuts and cotton resulted on soil losses of up to $90 \mathrm{t} \mathrm{ha}^{-1} \mathrm{yr}^{-1}$ (Clarke and Morrison 1987), far above the permissible level for tropical regions of $13.5 \mathrm{t} \mathrm{ha}^{-1} \mathrm{yr}^{-1}$ (Hudson 1971). The forested area in Viti Levu island covers almost $50 \%$ of its $10,389 \mathrm{~km}^{2}, 5-6 \%$ of which are planted (Leslie and Tuinivanua 2009) with similar proportions of planted hardwoods $(4.9 \%)$ and softwoods (4.5\%) and of natural mangrove forests (4.3\%) (Figure 1).

Fiji had the most aggressive forest plantation establishment policy of any of the Pacific Islands in order to meet the local demand for timber and to maintain a sustainable export trade in timber products, reinforced with the new markets opened by the Kyoto Protocol (IPCC 2006). The Fiji Hardwood Corporation Ltd (FHCL) and the Fiji Pine Limited (FPL) carry out the planting of mainly Mahogany and Pine respectively at a combined rate of around 9,200 $\mathrm{ha}^{-1} \mathrm{yr}^{-1}$ (Whiteman 2001).

Other aim of planting native trees is to support biodiversity conservation. Land-use changes, human-induced fragmentation, and invasive species are main threats to biodiversity conservation in small and remote islands (Martins 1993); confirmed since ancient times by palaeoecological records that reveal declines of forest taxa including palms, and a rapid invasion of introduced weed species (Prebble and Dowe 2008). In Easter Island flora decimation was almost complete after human colonization (Hunt and Lipo 2006); a natural rehabilitation is slow. More than 200 villages In Fiji established participatory conservation measures over $10800 \mathrm{~km}^{2}$ of sea and land (Watling and Chape 1992) which may be still insufficient for the long term preservation of species with unknown genetic plasticity (CBD 2010); therefore the reserves will need to be or relocated.
Most of these environmental problems can be mitigated with a land evaluation, which is the procedure of predicting land performance over time according to particular types of use (Rossiter, 1996). It's a valuable guide for planners to identify alternative land uses.
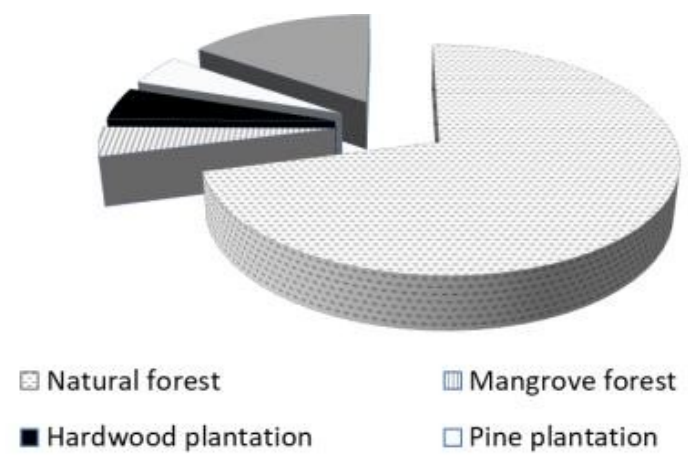

Scattered natural forest

Figure 1. Forest cover distribution over land area in Fiji Islands (Hasni 1997).

\section{PLANNING TREE PLANTATIONS WITH GIS}

GIS forestry applications mainly focused on resource inventory (including monitoring and analysis) and modelling to support decision making (McKendry and Eastman 1991) specially on forest growth (Riano et al. 2004) and hydrological issues (Ticehurst et al. 2003); however the planning of reforestation projects at local, regional and national levels can be improved by (1) constructing geographical databases of land suitability for tree species, (2) assessing the land suitability, and (3) selecting possible land areas for new plantations. The areas in the database can be classified on the basis of discontinuities in climate, geology (Mackey et al. 2008), biota (Clifford and Stephenson 1975) or on their integration. 
Land evaluations, traditionally based on soil surveys, predict land performance over time according to specific types of land use (Rossiter 1996). Carver (1991) applied a multiple-criterion evaluation (MCE) that identifies and map locations for the plantation of eucalyptus and pine trees according to variations on mean annual rainfall, rainfall regime, dry season length, mean maximum temperature of the hottest month, mean minimum temperature of the coldest month and mean annual temperature. The information that goes into the system determines suitability as incompatible (zero) or ideal (one) for each point of the area per vegetation type. The value of suitability depends on a set of physical and biological factors that favor or limit the growth of a tree species for decisionmaking (Felicisimo et al. 2002). The approach has been demonstrated at global and continental scales. In Finland, Kangas (1993) applied multi-criteria discrete methods to a reforestation plan by defining a three-level structure with three objectives: timber production, amenity, and impact on water. Nousiainen et al. (1998) added scenic values in a two-stage forest management application.

Plant hardiness is the ability of a plant to survive adverse growing climates such as drought, flooding, heat and cold. Tree species require specific growing environments to thrive; soil types, moisture levels and amount of sunlight are adjustable, but temperature and precipitation are hard to control (Gilmour 2019). In Fiji islands the changes on vegetation structure and composition respond to differences in temperature and rainfall (Walther et al. 2002). The rate of decrease of temperature is of 6.5 degrees $\mathrm{C}$ for each $1 \mathrm{~km}$ altitude change (Engineering ToolBox 2003). Choosing trees with hardiness levels appropriate to specific planting zones provides the best chance of landscaping success. In this paper I hypothesize that precipitation and altitude differences can determine potential areas for tree planting at large scale in Vitilevu island.

\section{MATERIALS AND METHODS}

Maps of forests, elevations and rainfall for Vitilevu Island were downloaded from the internet, their original file formats converted into TIFF and imported into Ilwis Open by geospatial data abstraction library. They were georeferenced by corner points used a 1451-meter grid cell size in the elevations map, a 1355-meter grid cell size in the rainfall map, and a 460-meter grid cell size in the forests cover map rainfall map with resulting root mean square errors (RMSE) of less than 0.6 in all cases. A vector map was digitized for each of the maps (figure 3), the corners of the maps were $17^{\circ} 02^{\prime} 26.10^{\prime \prime} \mathrm{S}, 176^{\circ} 23^{\prime} 43.94^{\prime \prime} \mathrm{E}$ top left and $18^{\circ} 44^{\prime} 41.40^{\prime \prime} \mathrm{S}$, $178^{\circ} 47^{\prime} 38.72$ "E bottom right. Contour maps (rainfall and elevation maps) were linearly interpolated, by rasterizing them and then calculating values for pixels that were not covered by segments. The forest cover raster map was converted into a binary map ( 0 and 1 values), then into a points format map to capture forested areas, and finally reconverted to raster format for further processing. The pixels of the resulting three raster maps were resampled to a common georeference of $966 \mathrm{~m}^{2}$ pixel size by bicubic interpolation, which determines the XY-coordinate of each pixel in the output map and calculates an interpolated value for each pixel using the 16 surrounding pixels of the input map. The areas to be planted per specie (Table 1) were found by applying decision rules. In a boolean operation the IF statement performs different things depending on a certain condition in the logical expression. The general syntax is 'If a then $b$ [else $c]$ ', where $a$ is a boolean expression, and $b$ and $c$ are either a single or a compound statement. Figure 2 is a simplified example of a map calculation process to solve OutMap1 $=$ IFF

((Landuse $=$ "Coffee") AND (DEM $>=20), 50,10)$. For example, areas to be planted with Pine are calculated: Pinus $=$ IFF ((_Alt' > 460) AND (_Alt' < 760) AND (_rainfall'

$>$ 600) AND (_rainfall‘<1000) AND (_land cover $\left.\left.{ }^{\star}=1\right), 1,0\right)$; where land cover $=1$ are areas without forests. In the case of the palm trees (sago and balaka) they need to be planted under cover so in their equations land cover $=1$. The results were compiled on Table 2 .

Landuse
\begin{tabular}{|c|c|c|}
\hline C & C & G \\
\hline F & F & $?$ \\
\hline G & C & C \\
\hline
\end{tabular}

DEM

\begin{tabular}{|c|c|c|}
\hline 45 & 40 & 30 \\
\hline$?$ & 15 & 10 \\
\hline 10 & 15 & 30 \\
\hline
\end{tabular}

Figure 2. Example of map reclassification with conditional function (Ilwis 2016).

Table 1. Ranges of ecological requirements per specie (AFT 2016).

\begin{tabular}{|l|c|c|}
\hline \multicolumn{1}{|c|}{ Specie } & Altitude & Rainfall \\
\hline & range (masl) & range (mm) \\
\hline Pinus caribaea & $460-760$ & $>600$ \\
\hline Tectona grandis & $0-1300$ & $1250-3750$ \\
\hline Leucaena leucocephala & $0-500$ & $<2500$ \\
\hline Sesbania grandiflora & $1000-2500$ & $0-800$ \\
\hline Metroxylon vitiense & $2000-2500$ & $0-700$ \\
\hline Balaka microcarpa & $>4000$ & $50-300$ \\
\hline Intsia bijuga & $0-600$ & $2000-3000$ \\
\hline Syzygium decussatum & $0-2000$ & $1500-6000$ \\
\hline Agathis macrophylla & $0-480$ & $4000-5000$ \\
\hline Swietenia macrophylla & $0-500$ & $1000-2000$ \\
\hline Gliricidia sepium & $650-3500$ & $5-1500$ \\
\hline
\end{tabular}

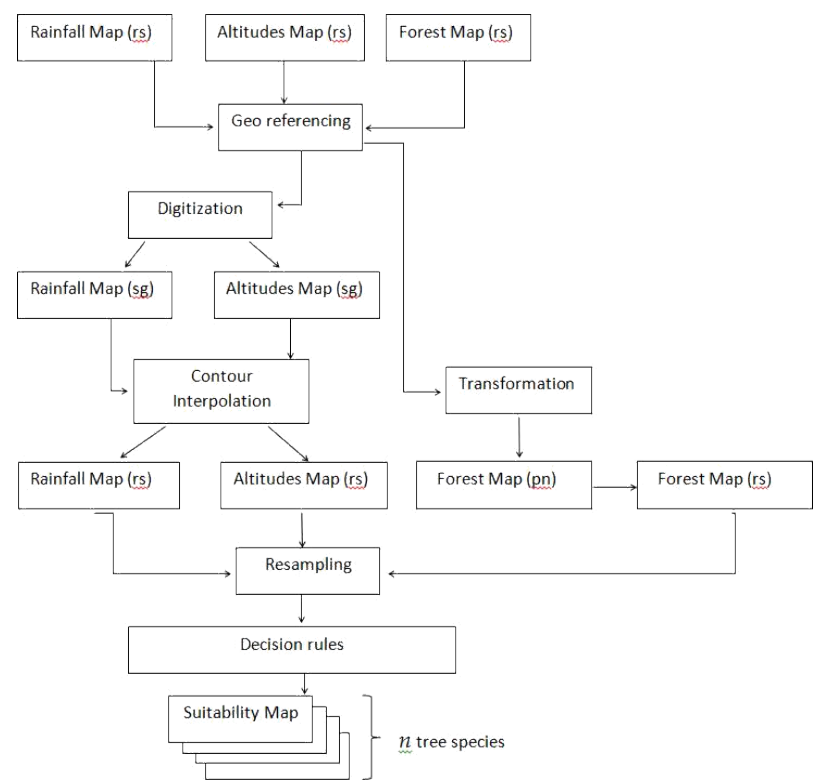

Figure 3. Method flowchart. Map formats are raster (rs), segment (sg) and points (pn). 

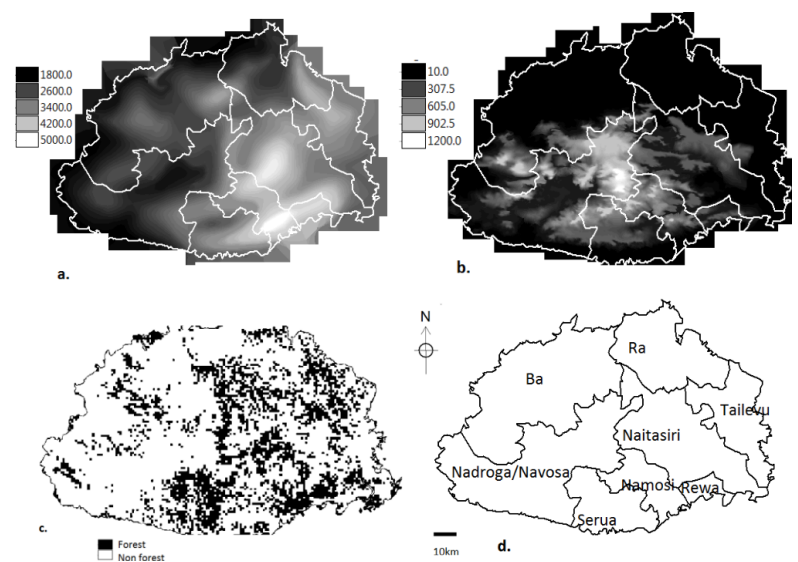

Figure 4. Rainfall (a), elevation (b), forest cover (c), and political (d) maps for Vitilevu Island.

Table 2. Resulting number of pixels and equivalent areas (ha) to be planted per specie.
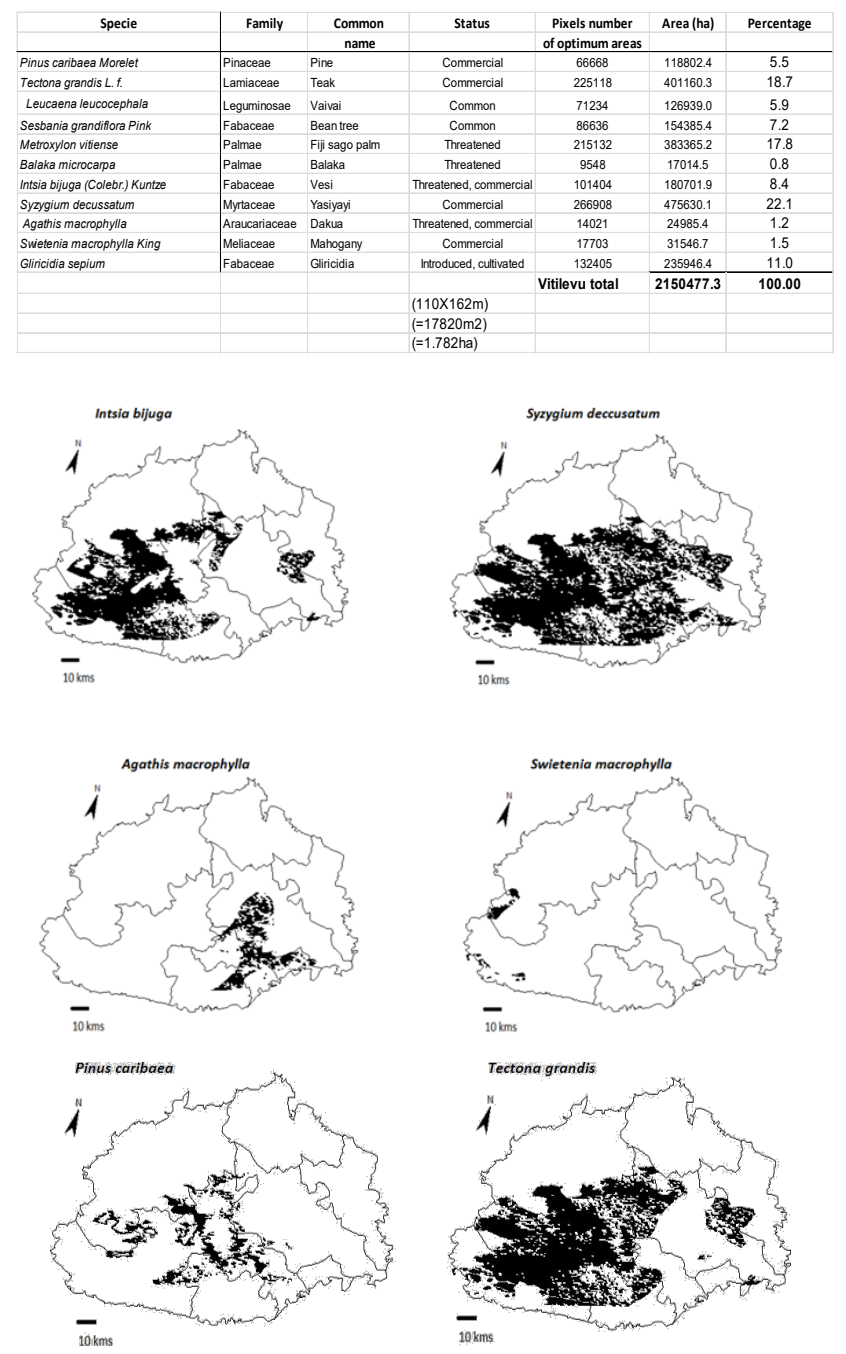
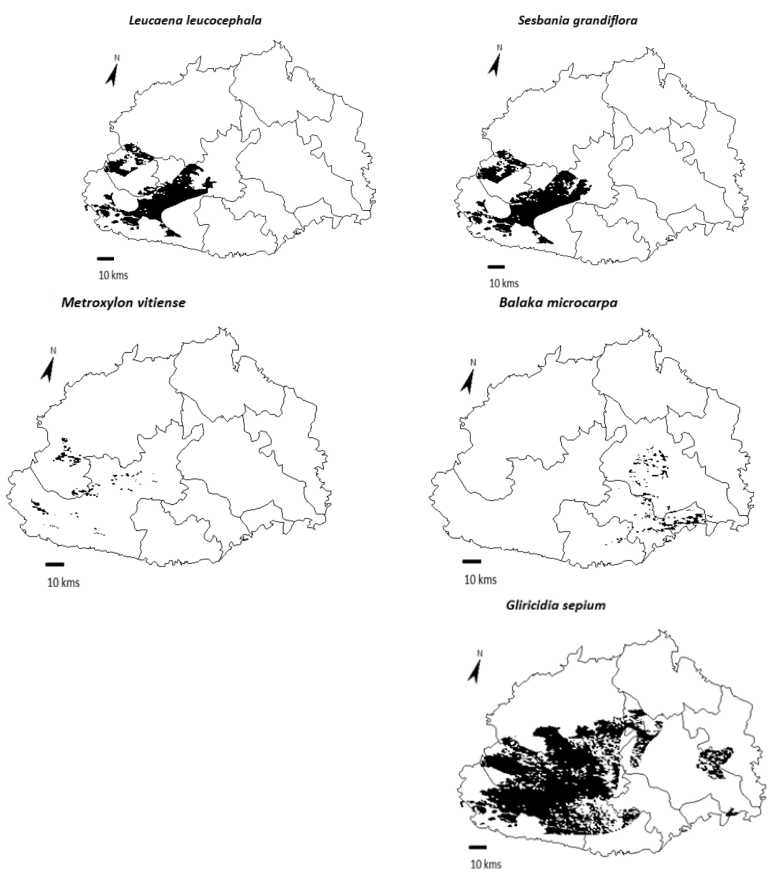

Figure 5. Potential areas to be planted per specie.

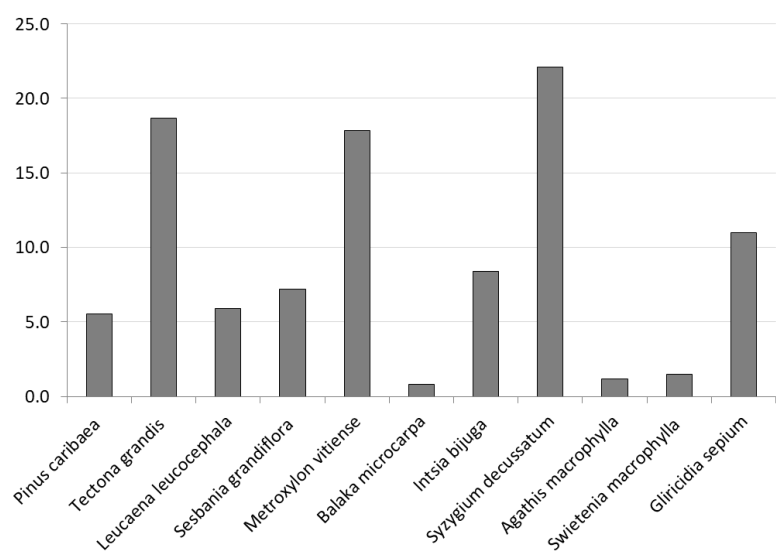

Figure 6. Total potential areas (\%) to be planted per specie in Vitilevu island

Table 3. Potential areas (ha) to be planted by specie and by province.

\begin{tabular}{|c|c|c|c|c|c|}
\hline Province & Agathis & Balaka & Gliricidia & Intsia & Leucaena \\
\hline Nadroga-Navosa & 1.124 & 0 & 138642.309 & 108605.38 & 54011 \\
\hline Serua & 3832.559 & 429.649 & 15443.479 & 14397.878 & 0 \\
\hline Namosi & 11852.018 & 2402.27 & 1007.666 & 727.509 & 0 \\
\hline Naitasiri & 22203.215 & 4300.71 & 18687.624 & 18686.781 & 0 \\
\hline Rewa & 4884.623 & 3318.89 & 308.257 & 308.257 & 0 \\
\hline Ba & 0 & 0 & 57695.763 & 45244.091 & 15453.9 \\
\hline Ra & 0 & 0 & 22.199 & 22.199 & 0 \\
\hline Tailevu & 0 & 0 & 4139.13 & 4139.13 & 0 \\
\hline TOTAL & 42773.539 & 10451.519 & 235946.427 & 192131.225 & 69464.9 \\
\hline & & & & & \\
\hline Mahogany & Pinus & Metroxylon & Sesbania & Syzigium & Teak \\
\hline & & & & & \\
\hline 2231.421 & 27540.25 & 3452.366 & 60346.998 & 145275.033 & 96310.783 \\
\hline 0 & 3021.312 & 0 & 0 & 24020.442 & 41153.012 \\
\hline 0 & 10270.83 & 0 & 0 & 29747.222 & 48525.89 \\
\hline 0 & 2289.588 & 0 & 0 & 66201.633 & 136872.29 \\
\hline 0 & 0 & 0 & 0 & 5557.337 & 17519.226 \\
\hline 5207.492 & 12398.56 & 3591.461 & 18282.984 & 57695.763 & 106621.52 \\
\hline 0 & 0 & 0 & 0 & 22.199 & 29989.444 \\
\hline 0 & 0 & 0 & 0 & 6670.378 & 82696.614 \\
\hline 7438.913 & 55520.54 & 7043.827 & 78629.982 & 335190.007 & 559688.779 \\
\hline
\end{tabular}




\section{RESULTS AND CONCLUSIONS}

According to Figure 6, Tectona grandis, Syzygium decussatum, Gliricidia sepium and Metroxylon vitiense are the most promising species to plant in the island in order of importance. Pinus caribaea is more apt to be planted in Nadroga Navosa province (27540.248ha) followed by Ba (12398.563ha) and Namosi provinces (10270.831ha). Tectona grandis has high prospects on $\mathrm{Ba}$ (106621.516ha), Nadroga-Navosa (96310.783ha), Naitasiri (136872.29ha) and Tailevu (82696.614ha) provinces, Leucaena leucocephala in NadrogaNavosa (54011.01ha) and Ba 15453.876ha) provinces, Sesbania grandiflora in Nadroga-Navosa (60346.998ha) and $\mathrm{Ba}$ provinces (18282.984ha), Metroxylon vitiense on $\mathrm{Ba}$ (3591.461ha) and Nadroga-Navosa (3452.366ha), Balaka microcarpa on Naitasiri (4300.705ha), Rewa (3318.891ha), Namosi (2402.269ha) and Serua (429.649ha) provinces, Intsia bijuga on Nadroga-Navosa (108605.376ha), Ba (45244.091ha), Naitasiri (18686.781ha) and Serua (14397.878ha) provinces, Syzygium decussatum in Nadroga-Navosa (145275.033ha), Naitasiri (66201.633ha), Ba (57695.763ha), Namosi (29747.222ha), and Serua (24020.442ha) provinces, Agathis macrophylla in Naitasiri (22203.215ha), Namosi (11852.018ha), Rewa (4884.623ha), and Serua (3832.559ha) provinces, and Swietenia macrophylla in Ba (5207.492ha) and Nadroga- Navosa (2231.421ha) provinces.

The genus Syzygium comprises about 1200 species (Chen and Craven 2015), most are evergreen trees and shrubs. Several species are grown as ornamental plants for their attractive glossy foliage, few produce edible fruits. Gliricidia $s p$. is a multipurpose tree that can be planted by cuttings or seedlings year round (Ratukalou 1998). Intsia is one of the most valued trees in the Pacific and Tectona grandis is an important tropical hardwood with a MAI of 4-17 $\mathrm{m}^{3} /$ ha/year (Pandey and Brown 2000). At this stage this work provides planners and investors with a firsthand report of land potential for the planting of endangered tree species or of high commercial value in the island. The proposed simple model is robust but can be improved by the addition of other thematic layers (soil fertility, land tenure, accessibility, and conservation areas), and by field checking for calibration.

\section{REFERENCES}

AFT., 2016. The Agroforestry database, Available at http://www.worldagroforestry.org/output/aftree-database [Accessed 15/12/2019].

Carver, S., 1991. Integrating multi-criteria evaluation with geographic information systems. International Journal of Geographical Information Systems 5, 321-339.

CBD., 2010. Secretariat of the Convention on Biological Diversity - Year in Review 2009. Montreal, 42 pages.

Chen, J; Craven, L; 2015: Syzygium P. Browne ex Gaertner, Fruct. Sem. Pl. 1:166. 1788, Flora of China Online 13, retrieved 3 May 2015.

Clarke, W; Morrison, R; 1987: Land mismanagement and the development imperative, in Fiji. In Brookfield H. and Blaikie P. Land Degradation and Society. Methuen, London, p.176-185.

Clifford, H; Stephenson, W; 1975: An Introduction to Numerical Classification. Systematic Zoology, 25 (1), 92-95.

Engineering ToolBox; 2003. Air Temperature and Altitude. [online] Available at: https://www.engineeringtoolbox.com/airaltitude-temperature-d_461.html [Accessed 29/04/2020].
Evans, J; 1992. Plantation forestry in the Tropics-tree planting for industrial, social, environmental, and agroforestry purposes, Oxford: Clarendon press.

Felicisimo, A; Frances, E; Fernandez, J; Gonzales-Diez, A; Varas, J; 2002. Modelling the potential Distribution of forests with a GIS. Photogrammetric Engineering and Remote Sensing 68: 455-461.

Gilmour; 2019. Interactive U.S. Planting Zone Map for 2019, downloaded from https://gilmour.com/planting-zoneshardiness-map.

Hasni, S; 1997. Country profile - Fiji, Tropical Forest Update, Vol. 7, No. 2, Food and Agriculture Organization of the United Nations, Rome, Italy.

Hudson, N; 1971. Soil Conservation. Cornell University Press, Ithaca, N.Y., $320 \mathrm{p}$.

Hunt, T; Lipo, C; 2006. Late colonization of Easter Island. Science 311: 1603-1606.

Ilwis; 2016. Available at www.Itc.nl/ilwis. [Accessed $15 / 09 / 2019]$.

IPCC; 2006. Intergovernmental Panel on Climate Change Guidelines for National Greenhouse Gas Inventories, the National Greenhouse Gas Inventories Programme, Eggleston H.S., Buendia L., Mi wa K., Ngara T. and Tanabe K. (Eds). Published: IGES, Japan.

Kangas, J; 1993. A multi-attribute preference model for evaluating the reforestation chain alternatives of a forest stand. For. Ecol. Manage. 59, 271-288.

Leslie, A; Tuinivanua, O; 2009. Asia Pacific forestry sector outlook study - Working Paper No. APFSOS II/ WP/ 2009/ 20, $24 \mathrm{p}$.

Mackey, B; Brown, T; 2008. Reconciling approaches to biogeographic regionalization: a systematic and generic framework examined with a case study of the Australian continent. Journal of Biogeography 35: 213-229.

Martins, A; 1993. The Azores - westernmost Europe: where evolution can be caught red-handed. Bol. Mus. Municipal Funchal S2: 181-198.

McKendry, J; Eastman, J; 1991. Applications of GIS in Forestry: A review. Available at www.nrac.wvu.edu/classes/for326/GISInForestryReviewPaper. pdf. [Accessed 10/04/2020].

Nambiar, E. K; 1999. Productivity and sustainability of plantation forests, BOSQUE 20(1):9-21.

Nousiainen, I; Tahvanainen, L; Tyrvainen, L; 1998. Landscape in farm-scale land- use planning. Scand. J. For. Res. 13, 477487.

Pandey, D; Brown, C; 2000. Teak: a global overview, Unasylva 201, Vol. 51 (3).

Prebble, M; Dowe, J; 2008. The late Quaternary decline and extinction of palms on oceanic Pacific islands. Quaternary Sci. Rev. 27, 2546-2567(doi:10.1016/j.quascirev.2008.09.015).

Ratukalou, I; 1998. Soil Degradation in the Republic of the Fiji Islands. Report to APO Seminar on Soil Degradation, Faisalabad, Pakistan, 19-24 October 1998, Asian Productivity Organization, Tokyo.

Riano, D; Chuieco, E; Codes, S; Gonzales-Matesanz, J; Ustin, S; 2004. Generation of crown bulk for Pinus sylvestris L. from lidar. Remote Sensing of Environment 92, 345- 352.

Rossiter, D; 1996. A theoretical framework for land evaluation (with discussion), Geoderma, 72: 165-202. 
Ticehurst, J; Cresswell, H; Jakeman, A, 2003. Using a physically based model to conduct a sensitivity analysis of subsurface lateral flow in south-east Australia. Environmental Modelling and Software 18, 729-740.

Walther, G; Post, E; Convey, P; 2002. Ecological responses to recent climate change. Nature 416, 389-95.

Watling, D; Chape, S; 1992. Environment Fiji - The National State of the Environment Report. IUCN. Gland, Switzerland. 154.

Whiteman, A; 2001. A review of the forest revenue system and taxation of the forestry sector in Fiji, FAO publication. 